\title{
Islamic religious education and radicalism in Indonesia: strategy of de-radicalization through strengthening the living values education
}

\author{
Syamsul Arifin \\ University of Muhammadiyah Malang \\ E-mail: syamsul.frahman67@yahoo.com \\ DOI: 10.18326/ijims.v6i1.93-126
}

\begin{abstract}
In Indonesian national system of education, Islamic religious education is compulsory for all levels of formal education. Taking into account such a position, Islamic religious education is potentially strategic in responding to some of the main issues in religious life. One issue examined in this paper is radicalism that continues to overshadow the dynamics of religious life in Indonesia. Although numerous attempts (mainly security approach) to eradicate radicalism have been taken, radicalism is still a prominent problem in Indonesia. This paper argues that Islamic religious education should be empowered in order to reduce the spread of radicalism. In order to bring these ideas into reality, this paper further offers Living Values E education (LVE) as a theoretical framework to develop Islamic religious education which is compatible with this goal.
\end{abstract}


Pendidikan agama Islam dalam sistem pendidikan nasional di Indonesia merupakan salah satu materi yang wajib diajarkan dalam institusi pendidikan formal mulai dari jenjang pendidikan dasar sampai ke jenjang pendidikan tinggi. Dengan mempertimbangkan posisinya yang demikian, pendidikan agama Islam memiliki potensi strategis untuk merespons beberapa persoalan utamanya dalam kehidupan agama. Salah satu persoalan yang hendak dikaji dalam tulisan ini adalah radikalisme yang terus membayangi kehidupan umat beragama di Indonesia. Meskipun telah dirancang berbagai upaya untuk membendung radikalisme terutama dengan menggunakan pendekatan keamanan, radikalisme ternyata masih eksis di Indonesia. Tulisan ini menawarkan pendidikan agama Islam sebagai salah satu institusi pendidikan yang perlu diberdayakan untuk membendung arus radikalisme. Untuk mewujudkan pemikiran tersebut, tulisan ini selanjutnya menawarkan living values education (LVE) sebagai suatu kerangka teoritik untuk mengembangkan pendidikan agama Islam.

Keywords: Islamic religious education; Living values education; Deradicalization

\section{Introduction}

Over the last two decades, religious life in Indonesia has been marked by a variety of dramatic changes. The most striking one took place within Islamic communities. As Islam is a religion of more than $80 \%$ of the total Indonesia's population, any changes occuredwithin Islamic communitiescan easily be noticed and analysed by academics comitted in conducting in-depth studies on the subject. One of the changes that attracted attention of researchers is the growing militancy of some Muslim groups which harbour an aspiration of making IndonesianIslam more authentic. During more than a century, in fact, there have been numerous Islamic movements that have significantly contributed both to the development of Islam itself and in the context of nationhood and statehood life. Muhammadiyah (established in 1912) and Nahdlatul Ulama or 
NU (established in 1926) are two major Islamic movements in Indonesia widely known not only for their ability to survive in a long span of time (more than a century), but also for their success in establishing a variety of social institutions which bring positive impacts not only for Muslims, but also for for Indonesian citizens, in general. However, since the collapse of the New Order regime, new Islamic religious groups emerged within Muslim society in the country. These groups, according to a number of studies, have more militant stance in struggling for an agenda and ideology which have never been stated explicitly both by Muhammadiyah and NU. Unlike Muhammadiyah and NU, these new Islamic religious groups openly campaign for, and even design a movement for the creation of a state ruled by religious principleswhich is popularly known as Islamic state. In their view, an Islamic state is seen as a guarantee for a thorough enforcement of Islamic law. ${ }^{1}$ Among many expressions which militant Islamic groups frequently roar in public sphere is the strong aspiration of establishing a religious state, or a state which is able to accommodate shari'a-based regulations. Inevitably, this is a field of study which attracts attention of scholars both domestic and abroad. For example, Greg Fealy and Sally White of the Australian National University (ANU), Canberra, Australia, published a book entitled Islam: Religious Life and Politics in Indonesia. ${ }^{2}$ This book is an edited volume of papers presented at

${ }^{1} \mathrm{Hizb}$ ut- Tahrir Indonesia ( HTI ), one of the Islamic movement called MC Ricklefs as political parties move beyond the electoral system ( the electoral system), even called the caliphate as bentul ideal Islamic state, including in Indonesia . See M.C. Ricklefs, "Religious Elites and the State in Indonesia and Elsewhere : Take- Overs Why Are So Difficult and Usually Do not Work ", in Hui Yew - Foong ( ed . ), Encountering Islam : The Politics of Religious Identities in Southeast Asia, Singapore: ISEAS , 2013 , 34-35. See also Ainur Rofiq al Amin, Membongkar Proyek Khilafah Ala Hizbut Tahrir di Indonesia, Yogyakarta: LKIS, 2012.

${ }^{2}$ Greg Fealy and Sally White (ed. ), Expressing Islam : Religious Life and Politics in Indonesia, Singapore : ISEAS 2008 , 7. See also Winfried Weck, Noorhaidi Hasan and Irfan Abubakar (ed), Islam in the Public Sphere, Jakarta : CSRC , 2011; Noorhaidi Hasan, The 
the Conference of 25th Indonesia Update conducted on 7-8September 2007at ANU.

In the above-mentioned volume, Fealy and White discussed the phenomenon. They maintain:

"...the growth in the number of Islamist parties and organisations, the implementation of sharia-based bylaws at the provincial and district level, and the introduction of more restrictive regulations on womens' movements and dress are cited as proof of iliberal trends within the Muslim community." ${ }^{3}$

The increasing boldness of Islamic militant groups in expressing their stance in the public space, primarily in the political sphere, is not without reason. Study conducted by Centre for Islam and Society (PPIM), Syarif Hidayatullah State Islamic University, Jakarta revealed two important factors. Firstly, the process of modernization has culminated in the crisis phase. It is characterized by the materialization of life, marginalization of spirituality, and the prominence of the values of rationality. On the other hand, as the second factor, the New Order authoritarian power has come to its end. This collapse has, in turn, paved the way for the process of decentralization and democratization, ${ }^{4}$ which also opened up more free space for the emergence of various religious groups led by Islamic community. ${ }^{5}$ The combination of these two factors has prompted massive emergence of new religious groups in Indonesia. In such a context, militant Islamic groups' claim of offering an alternativefor

Making of Public Piety Islam, Democracy and Youth in Indonesian Politics, Yogyakarta: SUKA Press, 2013.

${ }^{3}$ Greg Fealy and Sally White (ed. ), Expressing..., 7.

${ }^{4}$ Andy Fuller, "Reading Ahmadiyah and Discourse on Freedom of Religion in Indonesia”, dalam Bernhard Platzdasch and Johan Saravanamuttu (ed.), Religious Diversity in Muslim-majority States in Souteast Asia, Singapore: ISEAS, 2014, 75.

${ }^{5}$ Khamami Zada, Islam Radikal: Pergulatan Ormas-Ormas Islam Garis Keras di Indonesia, Jakarta: Teraju, 2002, 3. 
Indonesiato solve its multidimensional crisis can be situated. ${ }^{6}$ It is important to note that some religious groups maintain network with other groups which are known with similar names abroad. This phenomenon is better called transnational Islamic movements as represented by the case of Hizb ut-Tahrir Indonesia. Some other group, however, utilize domestic network, rather than transnational one. They are often referred to as home-grown religious groups such as the Islamic Defenders Front (FPI), Laskar Jihad (LJ) and the Indonesian Mujahidin Council (MMI). The presence of these religious groups has inevitably sparked public attention. This is mainlydue to a series of their actions which differ from mainstream Islamic groups' position. ${ }^{7}$ They, for example, often march along the streets demanding the implementation of Islamic law.HTI is known for its jargon: "Save Indonesia with shari'a."

Although scattered in various names and groups, these new religious groupsare actually located in the same ideological frame. M. Syafii Anwar offers the concept of militant Salafi Movement as a conceptualization to these developments. Anwar puts emphasis on militant characters inherent in the groups ranging from domain of religious understanding to the movement that is fundamentally implicated in various aspects of social life. ${ }^{8}$

${ }^{6} J a j a n g$ Jahroni dan Jamhari (ed.), Gerakan Salafi Radikal di Indonesia, Jakarta: Rajawali Pers, 2004, 13. See also, Ahmad Syafii Maarif, "Masa Depan Islam di Indonesia," dalam Abdurrahman Wahid (ed.), Ilusi Negara Islam: Ekspansi Gerakan Islam Transnasional di Indonesia, Jakarta: Gerakan Bhinneka Tunggal Ika, The Wahid Institute, and Maarif Institute, 2009,8

${ }^{7}$ Differences in outlook and action between Muhammadiyah and NU issues related to Islamic law discussed by Gordon P. Means. Instead of supporting agenda sharia formalization of new denominations of Islam, Muhammadiyah and NU, instead choosing a more substantive application of the scheme. Formalization of sharia according to Abdul Mukti, the young leaders of Muhammadiyah, it dries the ethical and humanitarian dimension of Islam . See Gordon P. Means, Political Islam in Souteast Asia, London: Lynne Rienner Publisher, 2009, 311.

${ }^{8}$ M. Syafii Anwar, Memetakan Teologi Politik dan Anatomi Gerakan Salafi Militan di Indonesia, dalam in M. Zaki Mubarak, Genealogi Islam Radikal di Indonesia: Gerakan, Pemikiran dan Prospek Demokrasi, Jakarta: LP3ES, 2007, xiii. 
Meanwhile, Martin van Bruinessen uses the concept of conservatism to capture the same phenomenon. This concept is used by Bruinessen to explain the changing face of Islam, from tolerant and compromising inclination to more hardened tendency as indicated by a series of conflicts and violence in some parts of Indonesia. Furthermore, Bruinessen also unveils the next phenomena that serve as evidentiary material which strengthen the leaning of conservatism in Indonesian Islam. Among the phenomenon is the over-reaction of Muslim public in general to liberalism following the publication of the Indonesian Ulema Council (MUI) fatwa which bans secularism, pluralism, and liberalism. ${ }^{9}$ This fatwa, according to Bruinessen, has in turn fostered intolerance against religious minorities in Islamic circles as experienced by Ahmadiyya and Shia. Based on this situation, Bruinessen asserts that Islam in Indonesia is facing a turn towards conservatism. Both Anwar's and Bruinessen's categories are basically in line with the concept of fundamentalism which is also often used to describe the existence of religious groups that subscribe to literal and scriptural understanding of the normative religious texts (the Quran and Sunna). Fundamentalism thus have integralistic understanding of Islam in the sense that Islam as a revelation of God brought by the prophets from the Prophet Adam to Prophet Muhammad is a complete and perfect religion or doctrine which regulates all human life. ${ }^{10} \mathrm{How}$ ever, it should be noted from the outset that the use term or idea of "fundamentalism"and"religious movements" in the post-New Order Indonesian context is is too loose. This situation closely relatesto the fact that there are many among Islam both individuals and groups that can

\footnotetext{
${ }^{9}$ Martin van Bruinessen (ed.), Concervative Turn: Islam Indonesia dalam Ancaman Fundamentalisme, Bandung: Mizan, 2014, 24-49.

${ }^{10}$ Haidar Nashir, Gerakan Islam Syariat: Reproduksi Salafiyah Ideologis di Indonesia, Jakarta: PSAP, 2007, 23-24.
} 
be classified as "fundamentalist" because of his belief in the truthof fundamental aspects of Islam, such as the Quran and Sunna. As an alternative to fundamentalism, Olivier Roy employs the term radicalism in the sense of a movement attempting at thinking of Islam as a political ideology with the entire social order in public life returned into the paradigm of absoluteness and the totality of God's power. ${ }^{11}$ Based on this analysis, it can be affirmed that religious radicalism has featured the development of religious life in the country post-New Order period. This development is important as radicalism has potential to transform into a religious movement which possibly brings destructive impacts on society. Moreover, there is also a neutral view on radicalism stating that fundamentalism is not really a threat as long as the idea of radicalism never been turned into real radical actions. ${ }^{12}$ But, since each religious movement has the potential to be transformed into reality especially if there are supporting factors, the development of radicalism should not be seen as a simple and neutral religious phenomenon.

Transformation of the most alarming radicalism is that it can evolve into terrorism, in the form of use of force (the deliberate use of violence) wrapped in religious language but mainly at the expense of "civil society" innocencece (against innocent people) as the target in order to achieve their main targets, which is political. ${ }^{13}$ This transformation has occurred in Indonesia since the beginning of 2000s. This transformation, according to the study of The SETARA Institute, is the third phase of transformation in the history of the Islamic movement in Indonesia. The SETARA

${ }^{11}$ Oliver Roy, Genealogi Islam Radikal, Yogyakarta: Genta Press, 2005, 25-26.

${ }^{12}$ Endang Turmudi dan Riza Sihbudi (ed.), Islam dan Radikalisme di Indonesia, Jakarta: LIPI Press, 2005, 5.

${ }^{13}$ As noted by Karen Armstrong, the main target of terrorism is a political movement both in terms of gain or maintain. See Karen Armstrong, Fields of Blood: Religion and the History of Violence, London: The Bodley Head, 2014, 313. 
Institute identifies this phase as the most important phase for taking terrorism as a mode of struggle. ${ }^{14}$ Actions and impact caused by the terrorist movement cannot be easily erased from the collective memory of the Indonesian people. This is reasonable as for a decade since the beginning of 2000, terrorism has been frequent feature of social life in Indonesia which has killeda considerable number of civilians coupled with material losses such as the destruction of property. Practically, those who are killed by the terrorist attacked, in the most cases, are not the real and main target. Victims are often chosen randomly (targets of opportunity) or selected (representative or symbolic targets). Therefore, the victims could be randomly fromdiverse social groups and background.. As in the case of the destruction of the WTC on September 11, 2001, the terrorist pointed to a selected target (representative or symbolic targets), in this case, its main target is the United States as a political entity. The Bali bombing displayed the similar case. Bali, as an icon of tourism in Indonesia and visited by considerably number of foreigners especially from Australia, a country which is perceived as part of the imperialist network which oppress Islamic countries, is selected as the target of terorrism act (targets of opportunity), Nevertheless, the impacts brought by the attack are not only material damage, but also immaterial damage and pressure (psychological). The same situation can also be seen from the case of post-

\footnotetext{
${ }^{14}$ The first phase of the Islamic movement was marked by the strengthening of the spirit of nationalism. Islamic figures more organized form associations as an instrument to arouse nationalist movement so that the Indonesian nation to be a nation that is free from colonialism. One of the copies of the Islamic movement in the first phase is the SI . In the second phase, the Islamic movement is marked by the strengthening of the cultural Islamic movement after the New Order regime was less accommodating to Muslim aspirations. In this phase appears many progressive Islamic thinkers such as Nurcholish Madjid, Abdurrahman Wahid, Munawir Sjadzali, Djohan Effendi, M. Dawam Rahardjo, Moelim Abdurrahman, Kuntowijoyo more affirm cultural Islam. See Ismail Hasani and Bonar Tigor Naipospos(ed.), Dari Radikalisme Menuju Terorisme: Studi Relasi dan Transformasi Organisasi Islam Radikal di Jawa Tengah E D.I. Yogyakarta, Jakarta: Pustaka Masyarakat Setara, 2012, 9-12.
} 
detonation WTC and the Pentagon which has caused tremendous impacts politically, psychologically, ${ }^{15}$ and shaked the world economy as well as increase the tension between America (West) with the Islamic world. ${ }^{16}$ In short, radicalization only led to loss, fear, threat, and damage; and this is incompatible with the substantive message of Islam as the giver of grace (well-being, tranquility, happiness, or preservation) of all mankind.

Although the security forces have detained some of the perpetrators of terrorism, but as it is said Ansyaad Mbai and Dawn Purwawidada, terrorism as difficult to eradicate. Even more seriously, new actors whith international networks emerged. Recent investigations managed to identified hundreds of Indonesian citizens who join the Islamic State(IS) and Nusro in Iraq and Syria have just been conducted. This developmentis an important indication that since the Bali bombing in 2001, the threat of terrorism, as predicted by Noor Huda Ismail, ${ }^{17}$ has not vanished.

\section{Stem the flow of radicalism}

Tracing the nature of of radicalism and terrorism is not an easy task, especially in a period when our world is marked by advanced inventionsin science and technology. This has resulted inunprecedented situation of the world whichis called by Thomas L. Friedmanas "the world is flat." ${ }^{18}$ In this "flat world, or in the classic concept of Marshall McLuhan called the"Global Village,"the exchange of ideas can quickly take place.

\footnotetext{
${ }^{15} 11$ September 2001 gave rise to the psychological effects such as fear, panic, anger and traumatic not only felt by American citizens but also the world's people globally. More details see Yasraf Amir Piliang, Hiperterorisme dan Hiperteknologi, in Farid Muttaqin \& Sukardi (Edit.), Teroris Serang Islam: Babak Baru Benturan Barat-Islam, Bandung: Pustaka Hidayah, 2001, 63.

${ }^{16}$ M. Abzar D., Teologi Teroris: Konstruksi ...., 1.

${ }^{17}$ Noor Huda Ismail, "Islam Nusantara di tengah Radikalisme", Tempo, 26 Juli 2015, 38-39.

${ }^{18}$ See Thomas L. Friedman, The World Is Flat, England, Penguin Books: 2006.
} 
A study conducted by Peter Mandaville on the development of transnational Islamic movements in South Asia and Southeast Asia, underlines the impacts of new information technology. Inevitably, it is one of the main factors which trigger the penetration of religious understanding and movements to a region. Three other major factors are: the exchange of scholarship and study, labor migration, and the obligation to perform the pilgrimage. ${ }^{19}$ Of the four main factors, the influence of new media is the most notable. Long before the booming of new media in this era, in 1999 John Naisbitt published a book titled, High Tech-High Touch: Technology and Our Search for Meaning, ${ }^{20}$ as a reminderof the emergence of a phenomenon which can be said as "drunk zone technology." This phenonemon is characterized by abundant devotion to technology, although some use for leisure. Facebook, a new media founded by Mark Zuckerberg, is a good example of this wave. Facebook is fantastic, as the number of its users continue to grow from year to year, of which Indonesia is the fourth largest Facebook users globally. ${ }^{21}$ The influence of information technology has created a variety of new media, according to Ariel Heryanto, cannot be taken lightly, as it has proved its ability to intervene and its capability to reshape social life of mankind throughout the world.The social life in Indonesia, is not an exception of this new wave. ${ }^{22}$

In relation to religious life, public access toa variety of reading materialswhich contain elements of radicalism available on many web-

${ }^{19}$ Peter Mandeville, "Transnational Islam in Asia: Background, Typology and Conceptual Overview", in Peter Mandeville et al, Transnational Islam in South and Southeast Asia: Movements, Networks, and Conflict Dynamics, Washington: The National Bureau of Asian Research, 2009, 13.

${ }^{20}$ In 2001, this book has been translated and published by Mizan by title, High TechHigh Touch: Pencarian Makna di Tengah Perkembangan Pesat Teknologi.

${ }^{21}$ http://techno.okezone.com/read/2014/09/22/55/1042737/indonesia-penggunafacebook-keempat-terbesar-di-dunia.

${ }^{22}$ Ariel Haryanto, Identitas dan Kenikmatan: Politik Budaya Layar Indonesia, Jakarta: Kepustakaan Populer Gramedia, 2015, 13. 
pages, have possiblyled a person to experiencing radical reasoning. As Muhammad Najib Azca uncovers in his After Jihad: A Biographical Approach to Passionate Politics in Indonesia, the involvement of cognition and emotionin information and events presented in can, in turn, attract people -especially those who are experiencing an identity crisis and the problems of life- into real radicalism activities, and even terrorism. ${ }^{23} \mathrm{In}$ this context, it isunderstandablethat in 2015 Indonesian government banned a number of websites thatcontain radical understanding of Islam andare regarded as the driving force for radicalism in the country. ${ }^{24}$

This policy was then aroused controversy. Nevertheless, regardless the controversy, it should be taken into account that this closure can be viewed as a precaution against the spread of radical understanding. Agus Surya Bakti maintains that vulnerable groups are easily infiltrated by terrorist ideology. In terms of age, the group indicated vulnerable to terrorist ideology are teenagers or young people who have a lot of free time to internet browsing, while on the one hand they are immature from various aspects, especially psychologically, intellectually, economically, and socially. Azca's studies specializing in youth radicalization reinforces this view. According toAzca, young people are vulnerableof being radicalized and may be further involved in radical movement of terrorists as they are in a transition phase in the growth of the age that allows them to experience an identity crisis. These conditions have inevitably facilitated the opening up of their cognition, which constitutes a micro-biological processes that bring them to the acceptance of new more radical ideas and understanding in the field of religion. ${ }^{25}$

\footnotetext{
${ }^{23}$ Muhammad Najib Azca, "After Jihad: A Biographical Approach toPassionate Politics in Indonesia” Ph.D Thesis, Amsterdam Institute for Social Science Research [AISSR], 2011, 90.

${ }^{24}$ http://internetsehat.id/2015/04/inilah-daftar-22-situs-islam-yang-diblokirmenkominfo/

${ }^{25}$ Muhammad Najib Azca, "Yang Muda, Yang Radikal: Refleksi Sosiologis Terhadap Radikalisme Kaum Muda di Indonesia Pasca-Orde Baru,” Maarif, Vol. 8, No.1 (Juli 2013),19-20.
} 
The contribution of socio-political context is important in paving the way for youth's involvement in radical movements. Azca calls this phenomenon as schism genesis, which is drastic changes occur in a political transition towards democracy. ${ }^{26} \mathrm{~A}$ combination of these vulnerability variables could bring negative impactson the formation of their perspectives on religion obtained from various internet sources containing radical understandingwhich are usually shallow, using black and white approach, and spread hatred against other parties who subscribe to other views. ${ }^{27}$ However, young people are not the only vulnerable groups of being radicals. In addition to individuals, the potential emergence of radicalism also found in some areas of the country vulnerable for conflicts caused by the grouping formed by various identities such as ethnicity, religion, economics, and politics. In accordance with this variable, riots in Tolikara, Papua, on July 17, 2015, can be perceived as a strong signal that attitudes and actions of radicals using a mode of violence can arise when intergroup relation within a society cannot be managed properly. This can also be an important indication that radicalism can be perpetrated bynot only particular religious group, only Islam for example, but also by other religious groups.

Aware of the "immortality nature" of radicalism and terrorism in Indonesia, efforts to eradicate it has been taken by many. It should be noted that security and militaristic approach are not effective ways to combat terrorism as it does not operate on the level of mind.As Agus Surya Bakti asserts: "The bullet is only able to penetrate the body, but are not able to penetrate the hearts and minds of radical-terrorists." ${ }^{28}$ In order to enrich the security approach and to prevent the breeding, development and dissemination of radical Islam, a softer approach of de-radicalization should be in-

\footnotetext{
${ }^{26}$ Muhammad Najib Azca, "Yang Muda..., 19-20.

${ }^{27}$ Agus SB., Darurat Terorisme: Kebijakan Pencegahan, Perlindungan dan Deradikalisasi, Jakarta: Daulat Press, 2014, 170-172.

${ }^{28}$ Agus SB., Darurat Terorisme..., 173.
} 
troduced. By this approach, not only those who have been involved in radical-terrorist actions are targeted, but also general public. This is meant as a strategy to prevent and at the same time as an early warning system against radicalism and terrorism. Thus, de-radicalization has a diverse meaning. One definition says that de-radicalization is an attempt to neutralize radical understanding of those who involved in acts of terrorism and the sympathizers. ${ }^{29}$ This definition limits the de-radicalization only for those who involved in the radical movements. Other than this definition, a broader definition and more relevant to this paper put forward by SETARA Institute.This definition formulates de-radicalization as early detection measures. In terms of target, SETARA Institute's definition extends the subjects of de-radicalization to a wide range of potential layer with different forms and variants respectively. In this context, the concept of Islam Nusantara (Nusantara Islam) is worth considering. According to Noor Huda Ismail, Nusantara Islam is expected to be key for the success of de-radicalization. ${ }^{30}$ From discussions at various forums, it is revealed that Islam Nusantarais apparently intended as an anti-thesis to radical understanding of Islam which became a justification for acts of violence including those using terrorism as a strategy. ${ }^{31}$ "Broadly speaking, Islam Nusantara will not teach someone to be radical. It will not teach enmity and hatred. In contrast, Islam teaches friendliness and can go hand in hand with the culture of civilization in Indonesia which is very polite, "explained Said Aqil Siraj. ${ }^{32}$

The terminology of Nusantara Islam is actually not something new in academic studies, especially in the perspective of archeology and history. ${ }^{33}$

\footnotetext{
${ }^{29}$ Asia Report No. 142, 19 November 2007, 1.

${ }^{30}$ Ismail Hasani dan Bonar Tigor Naipospos, Dari Radikalisme..., 191.

${ }^{31}$ Noor Huda Ismail, "Islam Nusantara...", 38-39.

${ }^{32}$ Bangga Islam Nusantara Mendunia” (http://www.jpnn.com/read/2015/07/13/ 314878/Bangga-Islam-Nusantara)

${ }^{33}$ See Azyumardi Azra, Jaringan Global dan Lokal Islam Nusantara, Bandung: Jakarta, 2002, and Uka Tjandrasasmita, Arkeologi Islam Nusantara, Jakarta: Kepustakaan Populer Gramedia, 2009.
} 
Through the study of Islam Nusantara with both perspectives, it can be obtained strong evidence for the acculturation process between Islam as a religion, on the one hand, with various local traditions that stretch from Sabang to Merauke, on the other. This shows that Islam is a religion which has grounded its value among the people of the archipelago, while radicalism intends to uproot Islam from the roots of its history in the archipelago; or in the words of Greg Fealy and Anthony Bubalo, radicalism offers and creates an Islamic identity that is generic or deculturated. ${ }^{34}$

\section{The strategic position of Islamic education}

Considering potential threat of radicalism, the idea of Nusantara Islam should be appreciated. However, the idea of Islam Nusantara will only detter at the level of discourse if it is not followed by strengthening the various social institutions which have long been owned by Muslim communities. One type of social institutions need to be strengthened and empowered in the context of eradicating radicalism is the educational institution. It should be restated here that education is an institution with strategic position in shaping and developing attitudes based on the views and values of certain. As an institution designed to fortify the penetration of radicalism, educational institutions should have a view and specific values that can be utilised to resist the logic of radicalism. Educational institutions which is seen as having a close linkage to stemming the radicalization agenda (de-radicalization) is Islamic religious education course.

What is an Islamic education, then? This question is intentionally raised due to a tendency among public and scholars to confuse Islamic religious

\footnotetext{
${ }^{34}$ Greg Fealy dan Anthony Bubalo, Jejak Kafilah: Pengaruh Radikalisme Timur Tengah di Indonesia, Bandung,: Mizan, 2007, 104.
} 
education with Islamic education. For example, learning or subjects of the Islamic religion in schools are sometimes referred to as "Islamic education" when more appropriate term should be is "Islamic religious education." ${ }^{35}$ The confusion on the semantic level is not independent of the various discourses and practices that are contrary to the education and development of Islam. At least two variants of education in Islamic circles that are often confused, namely: ${ }^{36}$

1. Education in Islam or Islamic education, namely education conceived and developed from the teachings and fundamental values contained in the two fundamental source of Islamic teachings, the Quran and Sunna. In the first sense, Islamic education can be either educational thought or theory which bases itself on or is developed from thesefundamental sources.

2. Islamic education is an attempt to teachand practice Islamic principles and valueswhich will further be part of a person's attitude and conducts. In this second sense of Islamic education can be formulated as: a) All activities carried out by someone or a particular institution to help a person or a group of learners in developing the teachings of Islam and its values; b) All phenomena or events of the encounter between two or more persons whose impact is embedded and/or growth of Islamic teachings and values on one or several parties.

Moving to further discussion, in this section should be mentioned the Indonesian Government Regulation No. 55 Year 2007 on Education of Religion and Religious Education. At this rule, there are, at least, two nomenclatures can be used to clarify the Islamic education and Islamic education institutions. The First nomenclature is religious education which

\footnotetext{
${ }^{35}$ Abdul Munir Mulkhan, Nalar Spiritual Pendidikan: Solusi Problem Filosofis Pendidikan Islam, Yogyakarta: Tiara Wacana, 2002, 55.

${ }^{36}$ Muhaimin, dkk., Paradigma Pendidikan Islam ..., 29-30; see also in Sukarji \& Umiarso, Manajemen dalam Pendidikan Islam: Konstruksi Teoritis-Filosofis dalam Menemukan Kebermaknaan Pengelolaan Pendidikan Islam, Jakarta: Mitra Wacana Media, 2014, 6.
} 
is defined as education which provides knowledge and shaping attitudes, personality, and skills of students in the practice of their religion, which is carried out at least through the subjects/courses at all sweet, levels and types of education. ${ }^{37}$ Under this rule, religious education is understood as an institution that provides education to prepare studentsto play a role which requires a mastery ofreligious knowledge and practice the teachings of his religion. ${ }^{38}$ With reference to the government regulations, an Islamic religious education in this paper uses the definition of the first nomenclature. Islamic religious education as such "limited" teaching materials in formal education given in primary education to higher education. While the Islamic educational institution is understood as religious education institution such as madrasas and boarding schools designed to prepare students who have expertise in the field of religious sciences.

Although it is limited as teaching materials and not designed as a special training for those who intend to pursue expertise in the fields of religion, Islamic education still play specific role. Therefore, it should also be able to play a strategic role in eradicating radicalism. Theoretically speaking, the embodiment towards these roles should have been easy to do considering the strong position that Islamic religious education assume in the context of national education system in Indonesia. As a continuation of ideological stance that Indonesia is a country based on the principle of One Godhead, government's policy in education gives adequate space to the existence of religious education, including Islamic religious education. This is in contrast to countries that adhere to the principle of secularism which defines the clear demarcation between reli-

\footnotetext{
${ }^{37}$ Indonesian Government Regulation Number 55 Year 2007 on Religious Education and Religious Educationin ChapterI (General Provisions) of paragraph(1).

${ }^{38}$ Indonesian Government Regulation No. 55 Year2007 on Religious Education and Religious Education in ChapterI (General Provisions) of paragraph(2).
} 
gion as a personal area (private sphere) and politics in the public, ${ }^{39}$ while in Indonesia religions are given a strategic position in the public sphere through a policy of religious education as a compulsory subject in primary education since up to higher education. This policy is long overdue. After five years declared itself as an independent and sovereign nation, Indonesia made the arrangement of the system of education in schools through the issuance of Law No. 1950 on Education in schools. ${ }^{40}$ These laws that regulate what is referred to in Chapter XII with "the teaching of religion inpublic schools." Article 20 contained the following provisions:

1. In public schools religious classes are conducted; parents determine whether their children will follow the lesson.

2. The methods of religious classes teaching in public schools is determined in the rules which are set by the Ministry of Education and Culture, in cooperation with the Minister of Religious Affairs. ${ }^{41}$

By the passing of time, the mandate of religious education is increasingly strengthened. In 2003, the government passed the Law of the Republic of Indonesia Number 20 Year 2003 on National Education System, which comtains a provision concerning religious education. This law states that religious education is one of compulsary subjects in all educational levels. ${ }^{42}$ The provision of Islamic religious education does not stop at providing legal protection in the form of legislation. Furthermore, as cited in the previous paragraph, the government has had a more detailed legal framework to regulate implementation of Islamic religious education. On Article 3, paragraph (1) Regulation No. 55 of 2007 con-

\footnotetext{
${ }^{39}$ H.A.R. Tilaar, Manifesto Pendidikan Nasional, Jakarta: Kompas, 2005, 230.

${ }^{40}$ H.A.R. Tilaar, Pembangunan Pendidikan Nasional 1945-1995, Jakarta: Grasindo, 1995, xxx.

${ }^{41}$ Dikutip dari H.A.R. Tilaar, Pembangunan Pendidikan..., 661.

${ }^{42}$ See ChapterX, Article 37.
} 
tained the following provisions: "Every educational unit on all lines, levels, and types of educations hall hold religious education." Then in Article 7paragraph(1) there is a provision:"Unit of education which organizes religious education is not in accordance with the provisions referred to in Article 3 paragraph(1) Article 4 paragraph(2) to paragraph (7), and Article5, paragraph(1) shall be subject to administrative sanctions in the form of a warning until after the closing was held coaching/mentoring by the Government and/or local government." Several articles in the regulation are indications of the strengthened position of Islamic religious education as a compulsary subject at all levels of formal education.

Upon consideration of such a position, Islamic religious education can be included as part of a scheme de-radicalization from religion point of view. By including into this scheme, Islamic religious education should also be understood as an activity gives a more moderate understanding of various key concepts in Islamic radicalism in perspective and attitude would lead to violence. Nasaruddin Umar ${ }^{43}$ gives an example of Surah Tawbah of the Quran, verse 5 as one of the verses that contains qital but often misunderstood by both Muslim and non-Muslims. Translation of this verse as follows:

"But when the forbidden months, then slay the idolaters wherever you find them, and capture them. Besiege them and spy on them in the reconnaissance. If they repent and establish worship and practice regular charity, then give them the freedom to walk. Allah is Forgiving, Merciful.”

Without understanding the historical context (asbab al nuzul), the verse could lead to the view that Islam justifies the use of violent and destructive way towards others or different religions. More profoundly, Umar

\footnotetext{
${ }^{43}$ Nasaruddin Umar, Deradikalisasi Pemahaman al-Qur'an $\mathcal{E}$ Hadist, Jakarta: Qanita, 2014, 4 .
} 
identifies eight Islamic concepts that need to be reinterpreted in moderation, namely: jihad, qital, apostasy, scribes, kafir dzimmi, kafir harbi, darus salam, and darul harbi. By the de-radicalization, says Umar, it is not intended to negate the key concepts; or meant to be an effort to silting faith, but rather as an effort to restore and realign against Islam as a religion of grace, peace, tolerance, respect for human rights, and emancipatory. ${ }^{44}$ In contrast, radical Islam put more emphasis on textual readings in the sense of "... ignores or rejects the socio-historical context of the Quran in interpretation." ${ }^{45}$ By understanding textually, the meaning of a text in the Quran is understood as a fixed formula, which closes any possibility of "change" or other meaning. The interpretation of text is regarded as universally applicable in any contexts. More fundamentally, a radical will not look at the dynamics of historical sociological circumstances surrounding the text. Syarif Hidayatullah gives an interesting explanation: ${ }^{46}$

“... A pattern of understanding and diversity of the" radical religion "always refers to the Quran, due to their readings that are too narrow and normative. They just made the Quran as the readings are taken for granted, which received direct and candid, do not need to be accompanied critical and historical readings. It would be very dangerous because they keep a distance from social reality. As if there is an assumption: "the important run" command "of the Quran, they can be said to have committed" virtue "and will get a reward with their Lord." This is where the problem of violent behavior in the name of religion."

In the same context, Abdullah Saeed gives an example of the meaning of the text relating to the law of apostasy. When it is understood

\footnotetext{
${ }^{44}$ Nasaruddin Umar, Deradikalisasi..., 342-384.

${ }^{45}$ Abdullah Saeed, Interpreting the Qur'an: Toward a ContemporaryApproach, London: Roudledge, 2006, 50.

${ }^{46}$ Syarif Hidayatullah, Islam "Isme-Isme": Aliran dan Paham Islam di Indonesia, Yogyakarta: Pustaka Pelajar, 2010, 93.
} 
textually, the argument in the form of hadith which reads, "man baddala dinahu faqtuluhu" (which can be textually be seen as order to kill whoever converts), Then it will lead to legal consequences in the form of execution against apostate. In this case, Abdullah Saeed and Hassan Saeed argue that although apostasy is still regarded as a sin, the punishment cannot be applied because it is contrary to the basic principles of Islam that recognizes the diversity of religion and the prohibition of conversion by force. "Islam is not a religion bent on persecuting all Reviews those who do not believe in it, or who leave it for one reason or another. Recognizes diversity Islam or religion, even though it does not approve of religious forms that it perceives have been derived from non-divine sources," said Abdullah Saeed and Hassan Saeed. ${ }^{47}$ Then he continued: "Islam regards life as testing ground, one of the most important aspects of which freedom to choose a belief system and a way of life." ${ }^{\prime 4}$

To avoid textual understanding, Abdullah Saeed stressed the importance of contextual understanding by considering the socio-historical context at the time the text was revealed: "... I refer to as contextualist emphasize the socio-historical context of the ethico-legal the content of the Quran and its subsequent Interpretations, "Saeed explains. ${ }^{49}$ It can be asserted that Saeed basically affirms the view of thought Fazlur Rahman (1919-1988) Pakistani Muslim. ${ }^{50}$ Contextual reading of the text as developed by Fazlur

\footnotetext{
${ }^{47}$ Abdullah Saeed and Hassan Saeed, Freedom of Religion, Apostasy and Islam, England: Ashgate, 2004, 86.

${ }^{48}$ Abdullah Saeed and Hassan Saeed, Freedom of Religion..., 86.

${ }^{49}$ Abdullah Saeed, Interpreting the Quran ..., 3.

${ }^{50}$ Once settled in Chicago as professor of Islamic studies at the University of Chicago, Fazlur Rahman develop contextual understanding that way actually initiated while still in Pakistan, the methodology calls with a double movement as a combination of inductive and deductive thinking. With a double movement, Fazlur Rahman offers an understanding of the al-Quran by taking two steps: First, understand the meaning of the statement of the Quran, by examining historical situations or problems where the answer and response to alQuran emerged. The second step of this first movement is a generalized statement of the
} 
Rahman and Abdullah Saeed will be rejected by radical Muslims. A contextual reading will provide opportunities to use human reasoning that tend to be critical and will instead be able to distort the real meaning of a text. Therefore, for them, the text of the Quran must be understood literally-as it is, since reason is deemed unable to provide the proper interpretation of the text. Radical believe that although certain parts of the scripture may seem to contradict one another, reason is not justified to some sort of compromise and interpreting these verses. ${ }^{51}$ Because Islamic religious education can be ensured in contact with some of the key concepts such as jihad that underlie radicalism should be given broad meaning by linking between text and context dialectically. Ali Ashghar Engineer analyzed:

“...invalid meaning of of jihad is widespread among certain Muslim leaders. For this group, jihad is interpreted as war or acts of violence. This phenomenon is a clear abuse for the meaning of jihad. The media played a role in spreading understanding wrong by not preaching the thoughts that oppose jihad meaning synonymous with violence or war. In fact, the concept of jihad in the Quran and Hadith has nothing to do with violence. The Quran does allow violence or war in certain situations that cannot be avoided or in self-defense. In al-Hajj (22): 39; which means: permission is given (to fight) for those who fight because they have been wronged. Indeed, Allah Almighty will help them. Indeed, a number of violent incidents have occurred in the history of Islam. But it happens because there are private interests (vested interest) by manipulating the verses of the Koran. Please also

specific answers that have social moral purpose of a general nature, which can be extracted from certain verses in the light of the historical background is also often expressed by the verse itself. See Fazlur Rahman, Islamic Methodology in History, Delhi: Adam Publishers and Distributors, 1994. See Also Abdullah Saeed, The Koran: an Introduction, London: Roudledge, 2008, 219-231.Top of Form.

${ }^{51}$ Azyumardi Azra, Pergolakan Politik Islam: dari Fundamentalisme, Modernisme hingga PostModernisme, Jakarta: Paramadina, 1996, 110. 
note that in Islamic history of warfare between the Islamic groups is much more prevalent than wars between Muslims and non-Muslims. In the book Futuh al-Buldan disclosed some facts about the battle between Muslims and non-Muslims. Some historians hostile to Islam view war against it in order to spread the teachings of Islam. Such understanding is too simplistic interpretation of jihad. This understanding is unfair towards Islam and towards history itself. Yet these wars are more prevalent because of conquest and hegemony of certain political groups. Misunderstanding of the meaning of jihad also occurs in groups Islamic Jihad at this time by way of misusing the interpretation of the verses of the Quran". ${ }^{52}$

It is obvious that the meaning of jihad should be based on religious values as substantive spirit of Islam which led to the formation of the community who has the welfare and peace. On this aspect, there is a need inform the proper meaning of jihad for thosewho adhere a reductive understanding of the jihad by entering the value of education as a construct in Islamic religious education. One example is the radical Islamic movement that had its own meaning to the different jihad with moderate Muslims who tend to give meaning as "soft" as the concept of "intellectual jihad" developed by Ziauddin Sardar. through this concept, Sardar itends to provide an awareness that the meaning and scope of jihad should not be reduced as a holy war as understood by radical Islamic circles. With the return of meaning, jihad will still find context actualization although not necessarily radically interpreted as holy war. In Indonesian context, the actualization of jihad according to a study conducted Muhammad Chirzin activity could be commanding the good and forbidding the evil in every room, especially the political, economic, and law. Explained further:

${ }^{52}$ Dewan Redaksi, Keragaman Makna Jihad (Pengantar Redaksi), in Harmoni Jurnal Multikultral \& Multireligius, Vol. VIII, No. 32 (OCtober-Desember 2009), 6-7. 
"Jihad is necessarily carried out in various forms are well-organized and responsible by involving all the potential of the nation, without discernment ethnic background, religion, race, and between groups, by integrating the mission of the Islamic struggle in the Indonesian struggle is ... Jihad today at least agenda continue reforms in various spheres of life. Both jihad in the socio-cultural, economic, political and legal, with jihad like hell without compromise against corruption, collusion and nepotism $(\mathrm{KKN})$. Because it has been pointed out that the irregularities in the various fields of life was not abated, even more rampant." ${ }_{33}$

It can thus be concluded that the development agenda of Islamic religious education as part of the de-radicalization scheme needs to be accompanied by two serious efforts. Firstly, reinterpretation of the key concepts in Islam is radically understood in more moderate and contextual understanding by taking into account the conditions of Indonesia. Referring back to Umar's recommendation on the urgency of re-interpretation of the key concepts in Islam (such asjihad, qital, apostasy, scribes, kafir dhimmi, kafir harbi, darus salam, and darul harbi), there are questions relating to the contextualization and relevance of these concepts to the conditions of Indonesia. Indonesia is not a religious state, or not an Islamic country, in a narrower sense! Therefore, the mere application of these concepts could create problems. The concept of kafir dhimmi is an example. According to Nazaruddin Umar, kafir dhimmi is a category based on principles of political jurisprudence (figh siyasah) which recognize two categories of kafir dhimmi (non-Muslims involved in hostilities with the Muslims) and kafir mu'ahad (non-Muslims committed by the Muslims for not mutually hostile).

As Indonesia is not an Islamic state in its formal sense, non-Muslim or Indonesian citizens who are not Muslim cannot be categorized as kafir

\footnotetext{
${ }^{53}$ Muhammad Chirzin, Kontroversi Jihad di Indonesia: Modernis vs Fundamentalis, Yogyakarta: Kelompok Pilar, 2006, 282.
} 
dhimmi who are attached to the obligation to pay tribute as a form of loyalty to the Islamic government. ${ }^{54}$ All Indonesian citizens assume the same position regardless their religious background. All people of religion in Indonesia can actualize themselves based on the concept of the political arena as the principle of democratic citizenship (citizenship as a political principle of democracy). This concept is understood as an individual citizen who has the right to be actively involved in public life, participate in decision making as well as the main one, to fight for the primacy (common good) as a common framework. ${ }^{55}$

Secondly, disseminating the results through a moderate interpretation of religious educational activity which promot certain values. Umar'sassertion that Islam a religion of grace (ahmatan lil Alamin), tolerance, respect for human rights, and emancipatory is basically an affirmation that in Islamicvalues are not contradictory to universal,perennial, and spiritual values which are absolute and do not change over time. ${ }^{56}$

\section{Towards Islamic education based LVE}

At practical level, the implementation of Islamic religious education is still needs to be closer to the frame of view. Because so far run formalistic religious education, activities merely to fulfill the will of the constitution indeed requires that Islamic religious education as a matter that must be given at all levels of education in formal education. In addition, Islamic religious education was also criticized because it still insists on studies that are too normative, less illustration of the socio-cultural context, and less directed to how to change the religious knowledge that cognitive "meaning" and "values" that need to be internalized within the participant learn-

${ }^{54}$ Nasaruddin Umar, Deradikalisasi Pemahaman..., 200-231.

${ }^{55}$ Robertus Robet dan Hendrik Boli Tobi, Pengantar Sosiologi Kewarganegaraan dari Marx sampai Agamben, Jakarta: Marjin Kiri, 2014, 4.

${ }^{56}$ Brahma Kumaris Educational Society, Education in Values and Spirituality...33. 
ers; ${ }^{57}$ or the education system is still struggling -which by Mohammed Abed al-Jabri, Moroccan thinker said as bayani epistemology, or in the language of M. Amin Abdullah called hadara al-nass (the religious culture that merely refers to the text), where he only wrestled with a stack of religious texts are mostly talking about the issues of fiqh alone. ${ }^{58}$ More basic criticism leveled by Haidar Bagir assessing religious education, including Islamic religious education have failed in forming a moral human beings. ${ }^{59}$ Though education is the "heart" and "backbone" of the future of the nation ${ }^{60}$ as well as the key to any effort to solve global problems ${ }^{61}$ and also one of the maturation processes of the quality of human life. ${ }^{62}$ To be more illustrative and empirical, jihad can be used as an example again. In textbooks and in the learning process of Islamic religious education narrative of jihad is usually associated with a history of warfare in Islam since the time of the Prophet. Certainly the way the narrative of this kind is not entirely wrong because the war in Islam is one indisputable. However, referring back to Haidar Bagir, the narrative portion of the battle is too big as the whole life of the Prophet is only traversed by the war. In fact, continued Haidar Bagir, the life of the Prophet in a span of approximately 23 years, equivalent to approximately 8000 days, the

\footnotetext{
${ }^{57}$ Muhaimin, dkk., Paradigma Pendidikan Islam: Upaya Mengefektifkan Pendidikan Agama Islam di Sekolah, Bandung: Remaja Rosdakarya, 2001, 111.

${ }^{58}$ Sri Minarti, Ilmu Pendidikan Islam: Fakta Teoritis-Normatif $\mathcal{E}$ Aplikatif-Normatif, Jakarta: Amzah, 2013, 8.

${ }^{59}$ Muhaimin Azzet, Urgensi Pendidikan Karakter di Indonesia, Yogyakarta: Ar -Ruzz Media, 2011, 9.

${ }^{60}$ Zian Farodis, Panduan Manajemen Pendidikan ala Harvard University, Yogyakarta: Diva Press, 2011, 7. Thus, the success of an action is determined by its success in improving and updating the education sector. Reza Aulia Bastian Refornasi Pendidikan: Langkah-langkah Pembaharuan dan Pemberdayaan Pendidikan dalam Rangka Desentralisasi Sistem Pendidikan Indonesia, Yogyakarta: Lapera Pustaka Utama, 2002, 24.

${ }^{61}$ Rutger Van Santen, dkk., 2030: Teknologi yang Akan Mengubah Dunia, Peterj.: Rahmani Astuti, Solo: Metagraf, 2012, 282.

${ }^{62}$ Dedy Mulyasana, Pendidikan Bermutu dan Berdaya Saing, Bandung: Remaja Rosdakarya, 2011, 2.
} 
percentage of time spent by the Prophet to fight only 10\%, or the equivalent of 800 days. In fact, according to the results of other studies cited by Haidar Bagir, refer to a smaller percentage is only $1 \%$, equivalent to $1 \%$. The question is, time outside the $10 \%$ or even $1 \%$, it is used for what the Prophet? Haidar Baqir deliberately asking such questions with the intention of looking for a foundation the argument that Islamic religious education can counteract radicalism, but at the same time can be a source which spawned radicalism when jihad is narrated through the war only with the portion of excess, especially when coupled with a history of war in the time of Caliph four and government post-Islamic caliphate. ${ }^{63}$

Starting fromthe opening of the education framework of Islam associated with the scheme of de-radicalization, on the one hand, and the criticism of Islamic religious education on the other, at this point I will put an emphasis on the importance of developing Islamic-based Living Values Education (LVE). LVE is an operational elaboration of the principles of education formulated by UNESCO, the UN agency for education. UNESCO formulates four principles of education, namely: learning to do, learning to know, learning to live together, and learning to be the true self (be coming, to be). At issue, how can we implement this principle in the fourth educational praxis. In 1996, about 20 teachers from around the world gathered at UNICEF headquarters in New York to discuss how to teach values. The meeting succeeded in formulating educational concept known values Living Values: An Educational Program (LVEP), which emphasizes the values of living methods in teaching values. By dropping the LVE as a reference for the development of Islamic education, the implication for developing Islamic religious education is primarily an educational value. In practice, LVE requires several steps as described below.

\footnotetext{
${ }^{63}$ http://haidar.baqir.com/pendidikan-agama-islam-dan radikalisme-pahamkeagamaan-di-indonesia/
} 


\section{Picture 1. The stages of LVE}

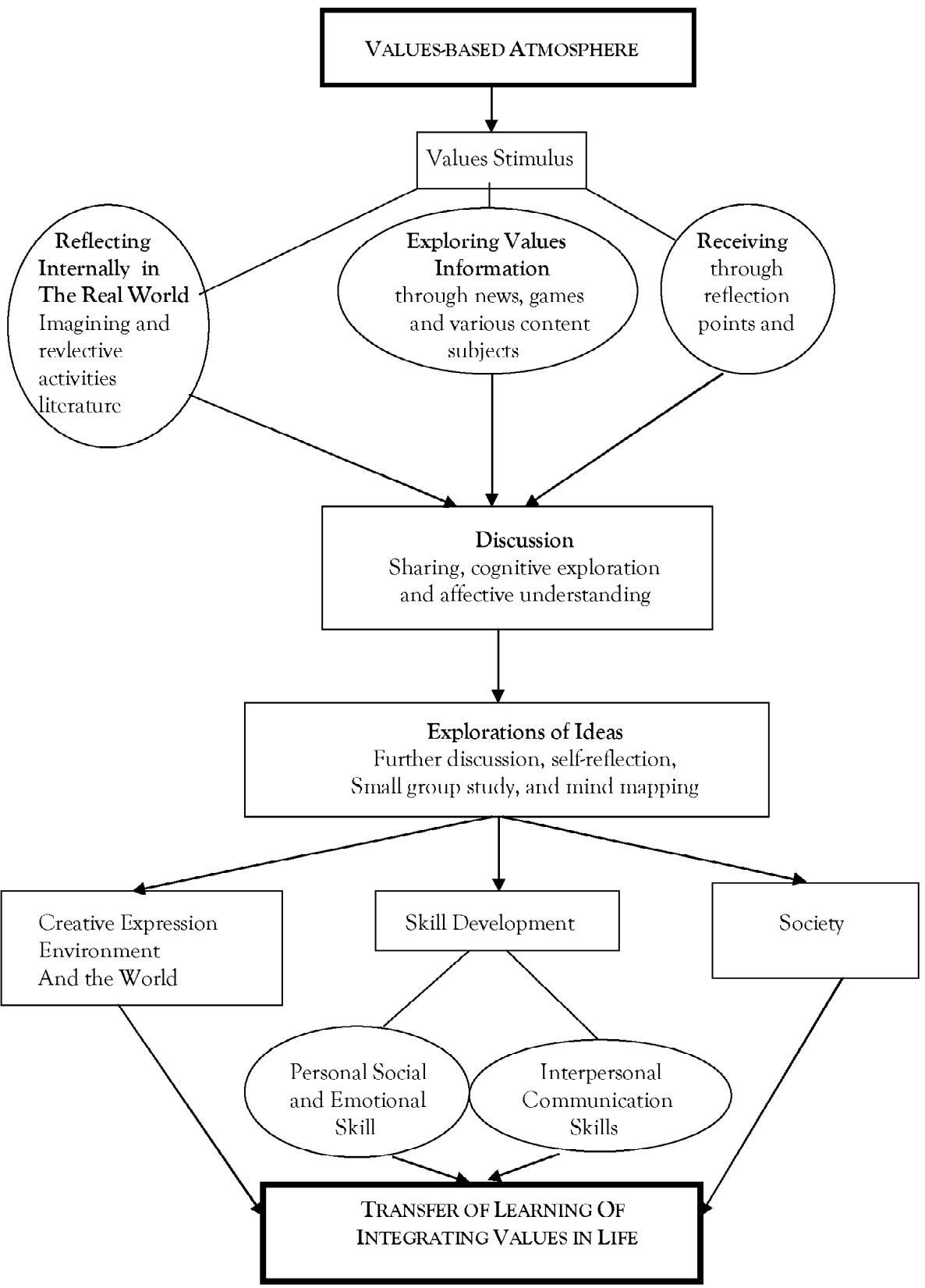


LVE stages begin with a stimulus values through the activity of reflection, exploration of values in the real world, and receive information through stories and literature. The results of these activities will be further discussed with the aim of exploring ideas. Through this exploration three ways can be developednamely creativity; skills development that consists of emotional and interpersonal communication skills; and sensitivity to the world community and the global environment. LVE stages ended in an effort to integrate learning into the values of life. The values emphasized in LVE frame consists of twelve values: peace, respect, love, tolerance, honesty, humility, cooperation, happiness, responsibility, simplicity, freedom, and unity. Explanation of each of the values as presented in the table below.

\section{Table1. Description of the twelve values in $\mathrm{LVE}^{64}$}

\section{Peace}

Peace is when we get along;

Peace is having positive through for my self and others;

Peace begins within each one of us.

\section{Respect}

Respect is knowing I am unique and valuable;

Respect is liking who I am;

Respect is listening to others.

\section{Love}

Love is caring and sharing;

Love is feeling save;

Love is wanting well for others.

\section{Co-operation}

Co-operation is helping one another;

Co-operation is working together with patience;

Cooperation is collective effort to reach a goal.

\section{IIappiness}

Happiness is knowing I am loved;

Happincss is giving cveryonc good wishes;

Happiness is love and peace inside.

\section{Responsibility}

Responsibility is being fair;

Responsibility is doing my share of the work;

Responsibility is taking care of my self and others.

\footnotetext{
${ }^{64} \mathrm{http}: / /$ www.livingvaluesnet/reference/excellence.html.
} 
Tolerance

Tolerance is accepting myself and others;

Tolerance is knowing we are all dififerent;

Tolerance is being understanding and opend-mind.

\section{Honesty}

Honesty is telling the truth;

Honesty is trust

Honesty is being true to yoursell and to others.

\section{Humility}

Humility is accepting everyone; Humility is self-respect and self-esteem; I Iumility is courage and confidence.

\section{Simplicity}

Simplicity is natural and beautiful; Simplicity is putting others first; Simplicity is appreciating the small things in life.

\section{Freedom}

Freedom is choice;

Freedom is living with dignity;

Freedom is when rights are balanced with responsibilitics.

\section{Unity}

Unity is togetherness;

Unity is collective strength and harmony;

Unity is personal commitment.

As the scheme shows, LVE is aimed at avoiding too verbal approach. In this appriach, the success of educational process is only seen in the ability of learners to recall certain values. Therefore, LVE is not "educational value" in the strict sense, but it is "living values education". If it is grasped in only a narrow sense, the actual value of character education in Indonesia is much more detailed as it contains such values as: being religious, honest, tolerance, discipline, hard work, creative, independent, democratic, curiosity, the spirit of nationalism, love homeland, appreciate the achievements, friends/communicative, love peace, bookworm, care for the environment, social care, and responsibility. The failure of education in Indonesia in developing the nation's character, according to Haidar Bagir, among other things, is caused by the verbalistic nature of values educated formal in educational institutions. This model of education also emphasizes memory of subjects rather than its implementation. 
The problem is, in the context of character education in Indonesia, students, are only encouraged to learn and memorize thesevalues. Consequently, the value of education in the strict sense which put greater emphasis on practical values are not achieved. Because more emphasis on caught, LVE considers it important creation of value-based environment that is more effective in shaping the personality of a person. This environment can be habit people in educational institutions (teachers/ lecturers, managers, administrative staff, student/student) in social interaction, or the environment in terms of the physical form of the availability of facilities and infrastructure are not only adequate but also looks neat and clean. In the process of the formation of personality, valuesbased environment is much more effective than verbal activity in the classroom. Environment is called the hidden curriculum ever initiated by Philip W. Jackson since the 1960s. ${ }^{65}$ Simply put, the hidden curriculum is not a collection of thoughts in writing is written in textbooks or other written sources, but a habituation, namely habituation-conditioning to behave in accordance with the values referenced.

\section{Concluding remarks}

By using LVE as a theoretical basis for the development of the Islamic religious education, Islamic religious education should be understood as an educational praxis value. In this context, LVE serves as a good perspective to determine both the substance and the process of, including how the values are ultimately forming a person's character. As definition of value suggests, value is a belief which motivates people's action on the basis of his choice. ${ }^{66}$ In other words, value is also understood as a norma-

\footnotetext{
${ }^{65}$ Rakhmat Hidayat, Pengantar Sosiologi Kurikulum, Jakarta: Rajawali Pers, 2011, 73-74.

${ }^{66}$ Definisi Gordon Alport sebagaimana diukutip Rohmat Mulyana dalam, Mengartikulasikan Pendidikan Nilai, Bandung: Alfabeta, 2004, 9.
} 
tive standard in determining a course of action, ${ }^{67}$ including one's interaction with people of diverse background. It is the culmination of a series of stages of LVE. If all values in the context of LVE are successfully integrated in the life of religious, inter-religious life, it theoretically can be an alternative way of setting the distance from the practice of intolerance, conflict and violence.. With reference to normative on universal values such as those developed in the LVE, an identity and symbolic-oriented perspective and will be transformed into a broader perspective which transcend beyond any identities. The twelve values introduced by LVE is primarily a virtue that can lead one to treat others as others treat to him.Or in other words, somebody will not treat others as others do not want to treat him the same thing. ${ }^{68}$ This is called the "golden rule" which, if adhered to and implemented in a consistent and sincere, life among religious believers can be established in the bonds of compassion or compassionate, or borrowing Karen Armstrong's word, mutual respect, mutual tolerance, avoid coercion, willing to work together, not arrogant or humble, promoting unity. In turn inter-religious life is always in a state of peace.

\section{Bibliography}

Al-Amin, Ainur Rofiq. Membongkar Proyek Khilafah Ala Hizbut Tahrir di Indonesia. Yogyakarta: LKIS, 2012.

Amir Piliang, Yasraf. Hiperterorisme dan Hiperteknologi, in Farid Muttaqin \& Sukardi (Eds.). Teroris Serang Islam: Babak Baru Benturan Barat-Islam. Bandung: Pustaka Hidayah, 2001.

Anwar, M. Syafii. Memetakan Teologi Politik dan Anatomi Gerakan Salafi Militan di Indonesia, dalam in M. Zaki Mubarak, Genealogi Islam Radikal di Indonesia: Gerakan, Pemikiran dan Prospek Demokrasi. Jakarta: LP3ES, 2007.

\footnotetext{
${ }^{67}$ Rohmat Mulyana, Mengartikulasikan Pendidikan Nilai..., 9.

${ }^{68}$ Thomas Lickona, Character Matters: Persoalan Karakter, Jakarta: Bumi Aksara, 2012, 17.
} 
Armstrong, Karen. Fields of Blood: Religion and the History of Violence. London: The Bodley Head, 2014.

Asia Report No. 142, 19 November 2007, 1.

Aulia Bastian, Reza. Refornasi Pendidikan: Langkah-langkah Pembaharuan dan

Pemberdayaan Pendidikan dalam Rangka Desentralisasi Sistem Pendidikan Indonesia. Yogyakarta: Lapera Pustaka Utama, 2002.

Azra, Azyumardi. Pergolakan Politik Islam: dari Fundamentalisme, Modernisme hingga Post-Modernisme. Jakarta: Paramadina, 1996.

Azra, Azyumardi. Jaringan Global dan Lokal Islam Nusantara. Bandung: Jakarta, 2002.

Azzet, Muhaimin. Urgensi Pendidikan Karakter di Indonesia. Yogyakarta: Ar -Ruzz Media, 2011.

Bruinessen, Martin van (ed.). Concervative Turn: Islam Indonesia dalam Ancaman Fundamentalisme. Bandung: Mizan, 2014.

Chirzin, Muhammad. Kontroversi Jihad di Indonesia: Modernis vs Fundamentalis. Yogyakarta: Kelompok Pilar, 2006.

Dewan Redaksi, "Keragaman Makna Jihad (Pengantar Redaksi)", in Harmoni Jurnal Multikultral $\mathcal{E}$ Multireligius, Vol. VIII, No. 32 (October-Desember 2009).

Farodis, Zian. Panduan Manajemen Pendidikan ala Harvard University. Yogyakarta: Diva Press, 2011.

Fealy, Greg and White, Sally (ed.). Expressing Islam : Religious Life and Politics in Indonesia. Singapore: ISEAS, 2008.

Friedman, Thomas L. The World Is Flat. England, Penguin Books: 2006.

Fuller, Andy, "Reading Ahmadiyah and Discourse on Freedom of Religion in Indonesia", in Bernhard Platzdasch and Johan Saravanamuttu (eds.). Religious Diversity in Muslim-majority States in Southeast Asia. Singapore: ISEAS, 2014.

Fealy, Greg dan Anthony Bubalo. Jejak Kafilah: Pengaruh Radikalisme Timur Tengah di Indonesia. Bandung,: Mizan, 2007.

Haryanto, Ariel. Identitas dan Kenikmatan: Politik Budaya Layar Indonesia. Jakarta: Kepustakaan Populer Gramedia, 2015.

Hasan, Noorhaidi. The Making of Public Piety Islam, Democracy and Youth in Indonesian Politics. Yogyakarta: SUKA Press, 2013.

Hasani, Ismail and Tigor Naipospos, Bonar (eds.). Dari Radikalisme Menuju Terorisme: Studi Relasi dan Transformasi Organisasi Islam Radikal di Jawa Tengah G D.I. Yogyakarta. Jakarta: Pustaka Masyarakat Setara, 2012. 
Hidayatullah, Syarif. Islam "Isme-Isme": Aliran dan Paham Islam di Indonesia. Yogyakarta: Pustaka Pelajar, 2010.

Hidayat, Rakhmat. Pengantar Sosiologi Kurikulum. Jakarta: Rajawali Pers, 2011. Ismail, Noor Huda, "Islam Nusantara di tengah Radikalisme", Tempo, 26 Juli 2015, 38-39.

Jahroni, Jajang dan Jamhari (eds.). Gerakan Salafi Radikal di Indonesia. Jakarta: Rajawali Pers, 2004.

Lickona, Thomas. Character Matters: Persoalan Karakter. Jakarta: Bumi Aksara, 2012.

Maarif, Ahmad Syafii, "Masa Depan Islam di Indonesia," dalam Abdurrahman Wahid (ed.). Ilusi Negara Islam: Ekspansi Gerakan Islam Transnasional di Indonesia. Jakarta: Gerakan Bhinneka Tunggal Ika, The Wahid Institute, and Maarif Institute, 2009.

Mandeville, Peter, "Transnational Islam in Asia: Background, Typology and Conceptual Overview", in Peter Mandeville et. Al. Transnational Islam in South and Southeast Asia: Movements, Networks, and Conflict Dynamics. Washington: The National Bureau of Asian Research, 2009.

Muhaimin, dkk. Paradigma Pendidikan Islam: Upaya Mengefektifkan Pendidikan Agama Islam di Sekolah. Bandung: Remaja Rosdakarya, 2001.

Mulkhan, Abdul Munir. Nalar Spiritual Pendidikan: Solusi Problem Filosofis Pendidikan Islam.Yogyakarta: Tiara Wacana, 2002.

Mulyasana, Dedy. Pendidikan Bermutu dan Berdaya Saing. Bandung: Remaja Rosdakarya, 2011.

Minarti, Sri. Ilmu Pendidikan Islam: Fakta Teoritis-Normatif $\mathcal{E}$ Aplikatif-Normatif. Jakarta: Amzah, 2013.

Nashir, Haidar. Gerakan Islam Syariat: Reproduksi Salafiyah Ideologis di Indonesia. Jakarta: PSAP, 2007.

Najib Azca, Muhammad, "After Jihad: A Biographical Approach toPassionate Politics in Indonesia" Ph.D Thesis, Amsterdam Institute for Social Science Research[AISSR], 2011.

Najib Azca, Muhammad, "Yang Muda, Yang Radikal: Refleksi Sosiologis Terhadap Radikalisme Kaum Means, Gordon P. Political Islam in Souteast Asia. London: Lynne Rienner Publisher, 2009.

Muda di Indonesia Pasca-Orde Baru," Maarif, Volume 8, Nomor 1 (Juli 2013). Mulyana, Rohmat. Mengartikulasikan Pendidikan Nilai. Bandung: Alfabeta, 2004. Rahman, Fazlur. Islamic Methodology in History. Delhi: Adam Publishers and Distributors, 1994. See Also Abdullah Saeed. The Koran: an Introduction. London: Roudledge 2008. 
IJIMS, Indonesian Journal of Islam and Muslim Societies, Volume 6, Number 1, June 2016: 93-126

Ricklefs,M.C, "Religious Elites and the State in Indonesia and Elsewhere: Take- Overs Why Are So Difficult and Usually Do not Work", in Hui Yew-Foong (ed.)., Encountering Islam: The Politics of Religious Identities in Southeast Asia. Singapore: ISEAS, 2013.

Robet, Robertus dan Tobi, Hendrik Boli. Pengantar Sosiologi Kewarganegaraan dari Marx sampai Agamben. Jakarta: Marjin Kiri, 2014.

Roy, Oliver. Genealogi Islam Radikal. Yogyakarta: Genta Press, 2005.

Saeed, Abdullah and Saeed, Hassan. Freedom of Religion, Apostasy and Islam. England: Ashgate, 2004.

Saeed, Abdullah. Interpreting the Quran: Toward a Contemporary Approach. London: Routledge, 2006.

Agus SB. Darurat Terorisme: Kebijakan Pencegahan, Perlindungan dan Deradikalisasi. Jakarta: Daulat Press, 2014.

Sukarji \& Umiarso. Manajemen dalam Pendidikan Islam: Konstruksi Teoritis-Filosofis dalam Menemukan Kebermaknaan Pengelolaan Pendidikan Islam. Jakarta: Mitra Wacana Media, 2014.

Tilaar, H.A.R. Pembangunan Pendidikan Nasional 1945-1995. Jakarta: Grasindo, 1995.

Tilaar, H.A.R. Manifesto Pendidikan Nasional. Jakarta: Kompas, 2005.

Tjandrasasmita, Uka. Arkeologi Islam Nusantara. Jakarta: Kepustakaan Populer Gramedia, 2009.

Turmudi, Endang and Sihbudi, Riza (eds.). Islam dan Radikalisme di Indonesia. Jakarta: LIPI Press, 2005.

Umar, Nasaruddin. Deradikalisasi Pemahaman al Qur'an EHadist. Jakarta: Qanita, 2014.

Van Santen, Rutger dkk. 2030: Teknologi yang Akan Mengubah Dunia. Peterj.: Rahmani Astuti. Solo: Metagraf, 2012.

Weck, Winfried, Hasan, Noorhaidi and Abubakar, Irfan (eds.). Islam in the Public Sphere. Jakarta : CSRC , 2011.

Zada, Khamami. Islam Radikal: Pergulatan Ormas-Ormas Islam Garis Keras di Indonesia. Jakarta: Teraju, 2002.

http://www.jpnn.com/read/2015/07/13/314878/Bangga-Islam-Nusantara Top of Formhttp://haidar.baqir.com/pendidikan-agama-islam-dan http://www.livingvaluesnet/reference/excellence.html. 